Anoba \& Cahapay, 2020

Volume 4 Issue 2, pp. 295-316

Date of Publication: $8^{\text {th }}$ October, 2020

DOI- https://doi.org/10.20319/pijtel.2020.42.295316

This paper can be cited as Anoba, J. L. D. E Cahapay, M. B. (2020). The Readiness of Teachers on Blended Learning Transition for Post-COVID-19 Period: An Assessment Using Parallel Mixed Method. PUPIL: International Journal of Teaching, Education and Learning, 4(2), 295-316.

This work is licensed under the Creative Commons Attribution-NonCommercial 4.0 International License. To view a copy of this license, visit http://creativecommons.org/licenses/by-nc/4.0/ or send a letter to Creative Commons, PO Box 1866, Mountain View, CA 94042, USA.

\title{
THE READINESS OF TEACHERS ON BLENDED LEARNING TRANSITION FOR POST-COVID-19 PERIOD: AN ASSESSMENT USING PARALLEL MIXED METHOD
}

\author{
Jeorge Louie D. Anoba \\ Department of Education, City Schools Division of Koronadal, Philippines \\ jeorge.anoba@deped.gov.ph \\ Michael B. Cahapay \\ College of Education, Mindanao State University, General Santos City, Philippines \\ mbcahapay@up.edu.ph
}

\begin{abstract}
Technology is seen by many as the "holy grail" that will address the constraints brought by the Coronavirus Disease 2019 (COVID-19) to the educational systems. The success, however, depends in part on the readiness of the teachers. This paper comprehensively assessed the readiness of teachers specifically on blended learning transition amid the COVID-19 crisis. Employing parallel mixed-method research, it involved elementary teachers from Carpenter Hill Elementary School, Mindanao, Philippines. The researchers used a survey questionnaire and interview guide data. This work revealed points of convergence, elaboration, and divergence in the data sets. An interesting point further underscored is that some quantitative and qualitative results may diverge, but challenges in these facets of blended learning can be turned into opportunities for teachers in the conduct of blended learning. A responsive, appropriate, and
\end{abstract}


relevant teacher preparation program should be developed based on this evidences toward an efficient and effective instructional implementation in the future.

\section{Keywords}

Teacher Readiness, Blended Learning, COVID-19, Assessment, Mixed Method

\section{Introduction}

The COVID-19 situation is ushering educational systems to a "new normal." The crisis is becoming a turning point that directs educational institutions to new modalities of instructional implementation. This challenge calls for an extensive preparation for changes in the educational landscape to ensure that the learning of children continues in this new period in human history.

Of the current alternative options being studied, technology has the most potent role in the changing landscape of education in the post-COVID-19 period. For example, in China that was the first epicentre of the virus, more than 180 million children were forced to stay at home. But while schools were shut down for quarantine, learning continued in a different mode using technology. It was done through a variety of online courses and electronic textbooks (Patrinos \& Shmis, 2020). Such a technology approach is the direction in which ongoing dialogues in many countries are seriously considering.

In the realm of technology, blended learning is dubbed as the "new normal" (Norberg et al., 2011) or the "new traditional model" (Ross \& Gage, 2006) in educational technology. Though ambiguities surround its definition, blended learning can be simply understood as an instructional approach that integrates traditional classroom methods and online digital methods (Graham 2013). It requires the physical presence of both teacher and student, with some elements of student control over time, setting, track, or pace (Huang et al., 20009). Given these characteristics of blended learning, it offers opportunities for use in education amid the COVID19 constraints.

The Department of Education (DepEd) in the Philippines recently expressed its possible action to implement a combination of traditional and online instruction for the planned 2020 class opening as the country continues to grapple with the COVID-19 pandemic. It is currently studying various alternative modalities of providing education to students. It believes that the learning process has to continue whether children remain at home or attend the school (Bernardo, 2020). With this possible transition to blended learning, schools need to plan virtual learning 
solutions that include assessing their capabilities based on the reliability of local power supplies, internet connectivity, and readiness of the teachers (Obana, 2020).

Decades of research have shown that school transitions to technology, in general, is contingent upon multiple interdependent factors. For one, Petko et al. (2018) confirmed that educational technology integration is dependent on the readiness of individual teachers. The level of teacher readiness to integrate educational technology is based on their views and skills. Many studies have suggested that determining the readiness of teachers is necessary for the success of the different modalities of technology integration (Balajadia, 2015; DiBella et al., 2015; Markle, 2016; Al-Awidi \& Aldhafeeri, 2017; Barde, 2017; Maimun et al., 2017; Christensen \& Knezek, 2017; Cuhadar, 2018; Norizan et al., 2018; Ifinedo et al., 2019; Mousa \& Kalonde, 2019; Ng \& Cheng, 2019; Zamir \& Thomas, 2019; Brooks \& Grajek, 2020).

Moreover, the readiness of the teachers is sensitive to contextual issues. Many studies have identified the interplay between readiness and various factors. For example, Bingimlas (2009) identified three factors that hinder the readiness of the teachers on technology integration: "lack of confidence, competence, and accessibility to resources" (p.9). On the other hand, Buabeng-Andoh (2012), Goktas et al. (2013), Singh and Chan (2014), and Maimun et al., (2017) underscored more particular factors such as teacher skills, school infrastructure, budget allocation, teacher confidence, quality technical support, workload, access to technology, teacher practices, the structure of education systems, nature of the curriculum, and peer support system. Exacerbated by the current crisis, Cahapay (2020a) stressed that different educational contexts should be considered at this time, so that reasonable changes will be better understood.

This study is significant in these difficult times when education continues to search for a solution to put education forward in the post-COVID-19 period. An assessment of teacher readiness to the needed transition process of schools to blended learning is the initial step toward the attainment of such a solution. The study of Tamban and Maningas (2020) demonstrated the practical use of enhancement program driven by evidence to improve overall teacher capacity. This present assessment study is also desired to provide a baseline support structure that will assist teachers in an efficient transition to a blended learning approach.

Thus, this paper aimed to comprehensively assess the readiness of the teachers on blended learning transition as a response to the impact of COVID-19 on the modalities of instructional implementation. 


\section{Methods}

This section presents the methods employed in this study. It includes the research design, sample, setting, instrument, gathering procedure, and data analysis.

\subsection{Research Design}

This present work employed a mixed-method research design. It is a form of inquiry that integrates both quantitative and qualitative data (Creswell, 2003). Furthermore, it is a type of research design in which qualitative and quantitative approaches are used in the types of questions, methods, collection, analysis, and inferences (Teddie \& Tashakkori, 2009).

Specifically, the researcher used a parallel mixed-method research design. The purpose of this design is "to obtain different but complementary data on the same topic" (Morse, 1991, p. 122) to best understand the research problem. This design that is based on different methods appears to address the intent of this study which is to comprehensively assess the readiness of the teachers on blended learning transition. Figure 1 shows the research design of this study.

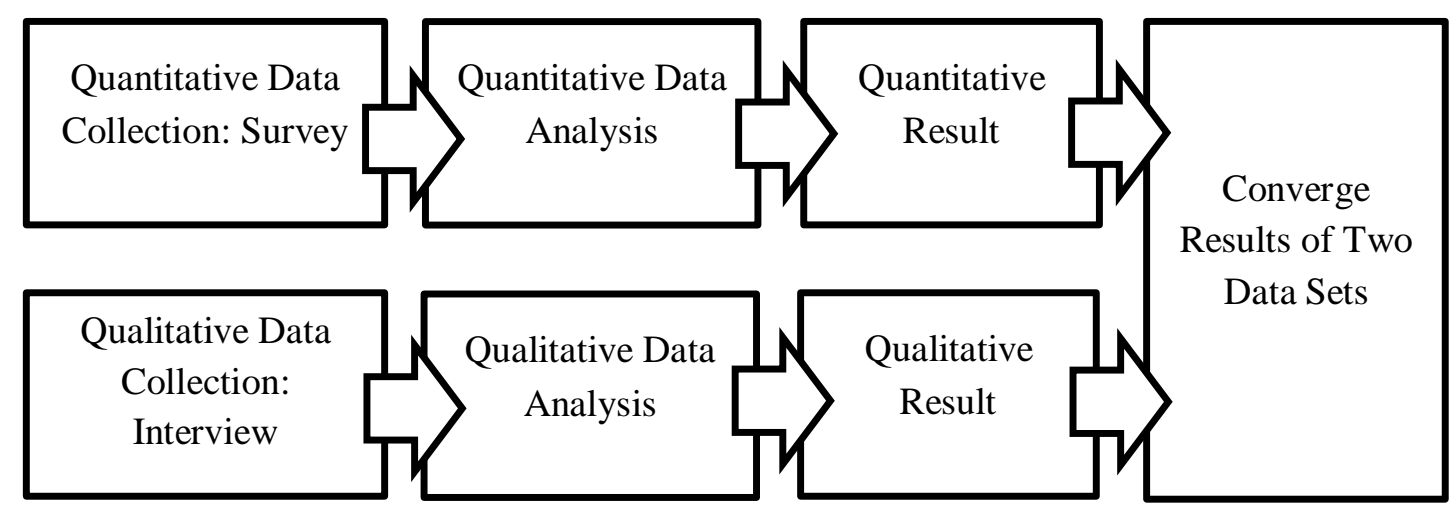

Figure 1: Parallel Mixed-Method Design of this Study

\subsection{Sample}

The respondents of this study were mainly selected based on purposive sampling. It is a non-probability sampling technique in which the researcher carefully chooses the participants considering the intention of the study with the expectation that every respondent will be able to furnish unique and rich data that are relevant to the study. Considering the sample size, the purposive sampling method is determined by data saturation (Suen et al., 2014).

This study involved all 18 teachers as respondents. They all participated in the survey, being teachers who will transition from traditional to a new modality of instruction. Furthermore, a pool of seven teachers representing each grade level was purposively organized to undergo a 
series of interviews. They were selected based on their relevant experience to provide answers for this study. All the participants of this research were selected regardless of their age, sex, tribe, rank, educational background, and teaching experience.

\subsection{Setting}

This study was conducted at Carpenter Hill Elementary School. It is located in Koronadal City, South Cotabato, Mindanao, Philippines. The school has minimum technology equipment in each classroom such as LED TV and projector. It also has an ICT laboratory, but its computer units need to be upgraded. Aside from the laptops acquired from the DepEd computerization program, all the teachers have their own. Internet connectivity is accessible within the school. With a population of 539 children, it currently attempts to improve its capacity to possibly implement a blended learning approach if the situation will permit.

\subsection{Instrument}

This study used a survey questionnaire titled "K to 12 Blended Teaching Readiness" adopted by Graham et al. (2019) to collect quantitative data on the readiness of the teachers. It consists of five factors such as foundations, planning, instructional methods and strategies, assessment and evaluation, and management. It further consists of 65 items. The psychometric properties of the said instrument have been tested. On the other hand, an interview guide developed by the researchers was used to further collect qualitative data about the readiness of the teachers. The tool contains the guidelines in conducting interviews and the key questions. The key questions revolved around the readiness of the teachers in terms of the different facets of blended learning transition.

\subsection{Gathering Procedure}

The researchers initially wrote a permission letter to the school head, explaining the goal of the research. Upon approval, the researchers through the school head collected the data in two phases corresponding to the mixed-method research design of the study. First, the quantitative phase began as questionnaires through Google links were sent to the teachers. The goal of the research as well as the procedure to answer the questionnaire were also explained to them. There was no disadvantage accrued to the research declared. The teachers answered synchronously or asynchronously, depending on what that works for them. The quantitative information was then collated and tabulated. The conduct of the qualitative phase followed. The researchers contacted the purposively sampled respondents online. Because of the current emergency, internet 
connectivity, and schedule conflict, the researchers sent the interview guide to the respondents online. The respondents answered the questions synchronously or asynchronously, thus qualitative information gathered was text-based. The quantitative information was then organized and coded.

\subsection{Data Analysis}

The quantitative data gathered for this study were analyzed using descriptive statistics such as frequency count and weighted mean. On the other hand, the qualitative data were subjected to thematic analysis. Both quantitative and qualitative results were then converged to obtain a comprehensive assessment of the readiness of the teachers on blended learning transition.

\section{Results}

This study sought to comprehensively assess the readiness of the teachers on blended learning transition as a response to the impact of COVID-19 on the modalities of instructional implementation. The data were gathered through multiple methods. They are presented cogently in the following sections.

\subsection{Result of Survey}

First, this study sought to determine the readiness of the teachers on blended learning transition through the survey. The mean per item was computed to consist of the weighted mean per indicator of readiness on blended learning transition. Based on the weighted mean, the descriptions are offered. The result is presented in Table 1.

Table 1: Survey on Readiness on Blended Learning Transition

\begin{tabular}{|l|l|l|}
\hline Indicators & Mean & Description \\
\hline Technical literacy & 2.47 & Slightly ready \\
\hline Digital citizenship & 2.38 & Slightly not ready \\
\hline Dispositions & 3.07 & Slightly ready \\
\hline Planning blended activities & 2.78 & Slightly ready \\
\hline Planning blended assessments & 2.53 & Slightly ready \\
\hline Personalizing instruction & 2.33 & Slightly not ready \\
\hline Facilitating student-student interaction & 2.17 & Slightly not ready \\
\hline Facilitating teacher-student interaction & 2.44 & Slightly ready \\
\hline
\end{tabular}




\begin{tabular}{|l|l|l|}
\hline Facilitating student-content interaction & 2.38 & Slightly not ready \\
\hline Implementing blended assessment & 2.36 & Slightly not ready \\
\hline Evaluating and reflecting & 2.34 & Slightly not ready \\
\hline Blended learning environment & 2.53 & Slightly ready \\
\hline Blended learning routines & 2.52 & Slightly ready \\
\hline Overall & 2.48 & Slightly ready \\
\hline
\end{tabular}

Legend: 1.00-1.60 not ready; 1.61-2.40 slightly not ready; 2.41-3.20 slightly ready; 3.21-4.00 ready

The result showed that the teachers were slightly ready on blended learning transition in terms of dispositions ( $M=3.07)$; planning blended activities ( $M=2.78)$; planning blended assessments $(\mathrm{M}=2.53)$; blended learning environment $(\mathrm{M}=2.53)$; blended learning routines $(\mathrm{M}=2.52)$; technical literacy $(\mathrm{M}=2.47)$; and facilitating teacher-student interaction $(\mathrm{M}=2.44)$.

On the other hand, the teachers were slightly not ready on blended learning transition when it comes to digital citizenship ( $\mathrm{M}=2.38)$; facilitating student-content interaction $(\mathrm{M}=2.38)$; implementing blended assessment ( $\mathrm{M}=2.36)$; evaluating and reflecting $(\mathrm{M}=2.34)$; personalizing instruction $(M=2.33)$, and facilitating student-student interaction $(M=2.17)$.

Overall, the teachers were slightly ready for the blended learning transition $(\mathrm{M}=2.48)$. This implies that the teachers have a moderate level of readiness to adopt blended learning modality as a response to the impacts of the COVID-19 pandemic on instructional implementation.

\subsection{Result of Interview}

This study also sought to determine the readiness of the teachers on blended learning transition through interviews. The common codes that appeared at least twice were grouped into categories. Then related categories were synthesized in an overarching theme. The summary of the result of the thematic analysis is presented in Table 2.

Table 2: Interview on Readiness on Blended Learning Transition

\begin{tabular}{|c|c|c|}
\hline Sample Codes & Category & Theme \\
\hline $\begin{array}{l}\text { Though I know the basics, I still need enrichment to } \\
\text { master this. }\end{array}$ & \multirow[t]{2}{*}{$\begin{array}{l}\text { Beginning level of } \\
\text { technical literacy }\end{array}$} & \multirow{4}{*}{$\begin{array}{l}\text { Technical } \\
\text { literacy ranging } \\
\text { from beginning } \\
\text { to developing } \\
\text { levels }\end{array}$} \\
\hline I can only manipulate basic operations on the computer. & & \\
\hline $\begin{array}{l}\text { I have average knowledge of using the software } \\
\text { application. }\end{array}$ & \multirow{2}{*}{$\begin{array}{l}\text { Developing a level } \\
\text { of technical } \\
\text { literacy }\end{array}$} & \\
\hline $\begin{array}{l}\text { My knowledge when it comes to technology for } \\
\text { instructional purposes is developing. }\end{array}$ & & \\
\hline I've always used technology in my teaching I am also & Awareness of & Direct, \\
\hline
\end{tabular}




\begin{tabular}{|c|c|c|}
\hline conscious of ethical issues that arise. & digital ethics & \multirow{4}{*}{$\begin{array}{l}\text { intentional } \\
\text { awareness of } \\
\text { digital } \\
\text { citizenship is } \\
\text { sought }\end{array}$} \\
\hline $\begin{array}{l}\text { We have been trained about ethical standards of being a } \\
\text { public servant. }\end{array}$ & $\begin{array}{l}\text { arising from the } \\
\text { experience }\end{array}$ & \\
\hline $\begin{array}{l}\text { I would say that I am learning progressively [when it } \\
\text { comes to ethical considerations]. }\end{array}$ & \multirow{2}{*}{$\begin{array}{l}\text { Awareness of } \\
\text { digital ethics needs } \\
\text { to be heightened }\end{array}$} & \\
\hline $\begin{array}{l}\text { I believe I have few knowledge when it comes to these } \\
\text { ethical considerations. }\end{array}$ & & \\
\hline $\begin{array}{l}\text { I've read a study on blended learning. I can probably } \\
\text { say that this kind of system is adaptable and effective. }\end{array}$ & \multirow{2}{*}{$\begin{array}{l}\text { Positive belief } \\
\text { about the } \\
\text { effectiveness of } \\
\text { blended learning }\end{array}$} & \multirow{4}{*}{$\begin{array}{l}\text { Favourable } \\
\text { dispositions } \\
\text { about blended } \\
\text { learning }\end{array}$} \\
\hline $\begin{array}{l}\text { I believe in the overall effectiveness of integrating } \\
\text { traditional classroom instruction and online digital } \\
\text { instruction. }\end{array}$ & & \\
\hline $\begin{array}{l}\text { Because of this pandemic that we have today, I think } \\
\text { online digital instruction is effective. }\end{array}$ & \multirow{2}{*}{$\begin{array}{l}\text { Affirmation about } \\
\text { the suitability of } \\
\text { blended learning }\end{array}$} & \\
\hline $\begin{array}{l}\text { With the kind of learners that we have right now, this } \\
\text { strategy will work for sure. }\end{array}$ & & \\
\hline $\begin{array}{l}\text { I have a lot of experiences in traditional but limited in } \\
\text { online instruction. }\end{array}$ & \multirow{2}{*}{$\begin{array}{l}\text { Needing inputs to } \\
\text { transition to an } \\
\text { online modality of } \\
\text { planning activities }\end{array}$} & \multirow{4}{*}{$\begin{array}{l}\text { Support to } \\
\text { transition to an } \\
\text { online modality } \\
\text { of planning } \\
\text { activities }\end{array}$} \\
\hline I still need to upgrade myself and adopt new trends. & & \\
\hline $\begin{array}{l}\text { I have skills in using technology and I am willing to } \\
\text { learn more about it. }\end{array}$ & \multirow{2}{*}{$\begin{array}{l}\text { Emerging skill to } \\
\text { transition to an } \\
\text { online modality of } \\
\text { planning activities }\end{array}$} & \\
\hline $\begin{array}{l}\text { I just know the basic ones but not the totality of the new } \\
\text { trend. }\end{array}$ & & \\
\hline $\begin{array}{l}\text { If I will be given materials and references, I will not } \\
\text { have any second thoughts to design a learner } \\
\text { assessment system. }\end{array}$ & \multirow{2}{*}{$\begin{array}{l}\text { Blended } \\
\text { assessment } \\
\text { conditional upon } \\
\text { material and time }\end{array}$} & \multirow{6}{*}{$\begin{array}{l}\text { Planning a } \\
\text { blended } \\
\text { assessment } \\
\text { grounded on } \\
\text { existing } \\
\text { practices and } \\
\text { factors }\end{array}$} \\
\hline $\begin{array}{l}\text { We need time to design an assessment system for us to } \\
\text { be prepared. }\end{array}$ & & \\
\hline $\begin{array}{l}\text { I am used to following the unified assessment system set } \\
\text { by the national in traditional instruction. }\end{array}$ & \multirow{2}{*}{$\begin{array}{l}\text { Grounded on the } \\
\text { existing } \\
\text { assessment system }\end{array}$} & \\
\hline There are a lot of rubrics to be used for this matter. & & \\
\hline $\begin{array}{l}\text { I can do it and explore along the way but not versatile } \\
\text { enough this time. }\end{array}$ & \multirow{2}{*}{$\begin{array}{l}\text { Dynamic planning } \\
\text { of blended } \\
\text { assessment system }\end{array}$} & \\
\hline $\begin{array}{l}\text { Assessment will depend upon the output of the learners } \\
\text { anyway. }\end{array}$ & & \\
\hline $\begin{array}{l}\text { The result of the pupils' performance will put in the } \\
\text { picture how are you going to design your instruction, } \\
\text { whether you will jump higher or just take a little leap. }\end{array}$ & \multirow{2}{*}{$\begin{array}{l}\text { Result of learner } \\
\text { performance as the } \\
\text { basis of the pace } \\
\text { and emphasis of } \\
\text { the next instruction }\end{array}$} & \multirow{4}{*}{$\begin{array}{l}\text { Emerging } \\
\text { capabilities in } \\
\text { personalizing } \\
\text { instruction }\end{array}$} \\
\hline $\begin{array}{l}\text { The result of learner performance will serve as the basis } \\
\text { on how much they learn and on what do they need to } \\
\text { learn. }\end{array}$ & & \\
\hline $\begin{array}{l}\text { Result of learner performance is used to determine } \\
\text { which instructional modality generated better learners } \\
\text { performance. }\end{array}$ & \multirow{2}{*}{$\begin{array}{l}\text { Result of learner } \\
\text { performance as the } \\
\text { basis of designing } \\
\text { an appropriate and }\end{array}$} & \\
\hline It will be my basis for designing instructions suited to & & \\
\hline
\end{tabular}




\begin{tabular}{|c|c|c|}
\hline my learners' needs. & $\begin{array}{l}\text { effective } \\
\text { instruction }\end{array}$ & \\
\hline $\begin{array}{l}\text { I am not yet oriented about the actual set-up in our } \\
\text { school so I'm not that well prepared as of the moment. }\end{array}$ & \multirow{2}{*}{$\begin{array}{l}\text { Non-readiness to } \\
\text { facilitate blended } \\
\text { student-student } \\
\text { interaction based } \\
\text { on the level of } \\
\text { teacher exposure }\end{array}$} & \multirow{4}{*}{$\begin{array}{l}\text { Impartial } \\
\text { readiness to } \\
\text { facilitate } \\
\text { blended student- } \\
\text { student } \\
\text { interaction }\end{array}$} \\
\hline $\begin{array}{l}\text { I am not well equipped and a neophyte in the new } \\
\text { educational system. The drastic change and } \\
\text { unpreparedness lead to lack of access. }\end{array}$ & & \\
\hline $\begin{array}{l}\text { Not yet ready because I look after to my learners on how } \\
\text { they respond to this new type of learning. }\end{array}$ & \multirow{2}{*}{$\begin{array}{l}\text { Non-readiness to } \\
\text { facilitate student- } \\
\text { student interaction } \\
\text { in blended learning } \\
\text { to consider the } \\
\text { nature of learners }\end{array}$} & \\
\hline $\begin{array}{l}\text { I am partially prepared because I believe this requires } \\
\text { intensive and strict health guidelines knowing that } \\
\text { learners by nature are sometimes not particular with } \\
\text { their actions and behaviours such as social distancing. }\end{array}$ & & \\
\hline $\begin{array}{l}\text { If we do video calls to our pupils, it seems that we do } \\
\text { have a face-to-face session with them as well. }\end{array}$ & \multirow{2}{*}{$\begin{array}{l}\text { Similarities } \\
\text { between } \\
\text { interactions in } \\
\text { traditional and } \\
\text { online } \\
\text { environments } \\
\end{array}$} & \multirow{4}{*}{$\begin{array}{l}\text { The affirmation } \\
\text { on blended } \\
\text { teacher-student } \\
\text { interaction } \\
\text { under } \\
\text { favourable } \\
\text { conditions }\end{array}$} \\
\hline $\begin{array}{l}\text { Online instruction and traditional instruction are still } \\
\text { the same that we communicate to the learners. }\end{array}$ & & \\
\hline $\begin{array}{l}\text { As a teacher, I can say yes yet there are some barriers } \\
\text { on the side of the learners like internet connection } \\
\text { availability and gadgets. }\end{array}$ & \multirow{2}{*}{$\begin{array}{l}\text { Didactic } \\
\text { interaction } \\
\text { dependent upon } \\
\text { materials and } \\
\text { support system }\end{array}$} & \\
\hline $\begin{array}{l}\text { The implementation of online instruction can be } \\
\text { effective only with parents' participation and } \\
\text { commitment. }\end{array}$ & & \\
\hline $\begin{array}{l}\text { I am not very confident with my skills to ensure that } \\
\text { pupils will find the content I design engaging. }\end{array}$ & \multirow{2}{*}{$\begin{array}{l}\text { Developing } \\
\text { engaging content } \\
\text { for learners } \\
\text { restricted by } \\
\text { different factors }\end{array}$} & \multirow{4}{*}{$\begin{array}{l}\text { Ambivalence on } \\
\text { facilitating } \\
\text { blended student- } \\
\text { content } \\
\text { interaction }\end{array}$} \\
\hline $\begin{array}{l}\text { Still trying to figure out how to have an engaging } \\
\text { designed content yet. }\end{array}$ & & \\
\hline $\begin{array}{l}\text { No, because of some different factors such as my limited } \\
\text { experiences, availability of resources and the } \\
\text { participation of the parents themselves. }\end{array}$ & \multirow{2}{*}{$\begin{array}{l}\text { Expression of need } \\
\text { to hone skills in } \\
\text { designing content } \\
\text { engaging to the } \\
\text { learners }\end{array}$} & \\
\hline $\begin{array}{l}\text { I still need guidance from experts to enhance further the } \\
\text { skills that I already have. }\end{array}$ & & \\
\hline $\begin{array}{l}\text { There are ample materials present online designed } \\
\text { validated by the DepEd, so this is not a problem. }\end{array}$ & \multirow{2}{*}{$\begin{array}{l}\text { Capitalizing on } \\
\text { existing } \\
\text { assessment for the } \\
\text { blended } \\
\text { assessment }\end{array}$} & \multirow{4}{*}{$\begin{array}{l}\text { Need to bridge } \\
\text { traditional and } \\
\text { online } \\
\text { assessment } \\
\text { implementation }\end{array}$} \\
\hline $\begin{array}{l}\text { There are many methods to do to assess a pupil's } \\
\text { performance whether it is a physical or online } \\
\text { classroom. }\end{array}$ & & \\
\hline $\begin{array}{l}\text { We are highly needed some seminar-workshop online on } \\
\text { how to assess both physical classroom and online } \\
\text { classroom. }\end{array}$ & \multirow{2}{*}{$\begin{array}{l}\text { Need for technical } \\
\text { assistance on } \\
\text { blending } \\
\text { modalities of } \\
\text { assessment }\end{array}$} & \\
\hline $\begin{array}{l}\text { I can. However, I need to have adequate training for } \\
\text { effectiveness and efficiency. }\end{array}$ & & \\
\hline
\end{tabular}




\begin{tabular}{|c|c|c|}
\hline $\begin{array}{l}\text { Yes, results will be the basis of the improvement of } \\
\text { teaching methods, instructional materials, and } \\
\text { assessment strategies. }\end{array}$ & \multirow{2}{*}{$\begin{array}{l}\text { Results of blended } \\
\text { learning as the } \\
\text { basis for } \\
\text { instructional } \\
\text { improvement }\end{array}$} & \multirow{4}{*}{$\begin{array}{l}\text { The reflective } \\
\text { practice of } \\
\text { teaching in a } \\
\text { blended } \\
\text { learning setup }\end{array}$} \\
\hline $\begin{array}{l}\text { The results will become the basis of crafting or } \\
\text { improving teaching methods, instructional materials, } \\
\text { and assessment strategies. }\end{array}$ & & \\
\hline $\begin{array}{l}\text { Yes, because it indicates how well the method, } \\
\text { techniques, and test measures successfully applied. }\end{array}$ & \multirow{2}{*}{$\begin{array}{l}\text { Results of blended } \\
\text { learning as the } \\
\text { yardstick of } \\
\text { instructional } \\
\text { effectiveness }\end{array}$} & \\
\hline $\begin{array}{l}\text { Yes, since pupil performance would tell us, teachers, if } \\
\text { the contents of teaching and learning we designed are } \\
\text { working with them and the set goals of DepEd is } \\
\text { achieved. }\end{array}$ & & \\
\hline $\begin{array}{l}\text { I am confident with regards to these modalities provided } \\
\text { that the materials must be prepared appropriately for } \\
\text { effective learning to happen. }\end{array}$ & \multirow{2}{*}{$\begin{array}{l}\text { Technical support } \\
\text { sought for } \\
\text { establishing an } \\
\text { online learning } \\
\text { environment }\end{array}$} & \multirow{4}{*}{$\begin{array}{l}\text { Blended } \\
\text { learning } \\
\text { environment } \\
\text { dependent on } \\
\text { support }\end{array}$} \\
\hline $\begin{array}{l}\text { I don't have enough confidence to establish classroom } \\
\text { procedures that promote pupils to efficiently learn both } \\
\text { in the traditional and online classroom due to lack of } \\
\text { materials }\end{array}$ & & \\
\hline $\begin{array}{l}\text { Traditional classroom settings are very common, and I } \\
\text { am very confident to establish that. But in online } \\
\text { classroom settings, this is new to us especially for us } \\
\text { teachers in the DepEd. }\end{array}$ & \multirow{2}{*}{$\begin{array}{l}\text { Capability to } \\
\text { prepare a } \\
\text { traditional } \\
\text { classroom learning } \\
\text { environment but } \\
\text { more knowledge } \\
\text { sought for online }\end{array}$} & \\
\hline $\begin{array}{l}\text { I don't know the standard operating procedures in } \\
\text { delivering the combined traditional and online } \\
\text { classroom. }\end{array}$ & & \\
\hline $\begin{array}{l}\text { I am confident enough to say that I am capable of } \\
\text { creating an environment that allows pupils to learn both } \\
\text { in the traditional classroom and online classroom. }\end{array}$ & \multirow{2}{*}{$\begin{array}{l}\text { Establishing } \\
\text { blended learning } \\
\text { routine based on } \\
\text { self-efficacy }\end{array}$} & \multirow{4}{*}{$\begin{array}{l}\text { Blended } \\
\text { learning } \\
\text { routines based } \\
\text { on enabling } \\
\text { factors }\end{array}$} \\
\hline $\begin{array}{l}\text { I can establish blended learning routines by using my } \\
\text { abilities and knowledge on how to handle both } \\
\text { traditional and online classroom. }\end{array}$ & & \\
\hline $\begin{array}{l}\text { The teacher training and online training, as well as my } \\
\text { experience as a classroom teacher, makes me capable } \\
\text { as a teacher. }\end{array}$ & \multirow{2}{*}{$\begin{array}{l}\text { Establishing a } \\
\text { blended learning } \\
\text { routine based on } \\
\text { exposure }\end{array}$} & \\
\hline $\begin{array}{l}\text { I think I know the basic skills in using ICT. I already } \\
\text { taught my pupils in grade five the basic information of } \\
\text { ICT as one of the components of our EPP subject. }\end{array}$ & & \\
\hline
\end{tabular}

Theme 1: From beginning to developing technological literacy. Based on their assessment of their knowledge, the participants expressed varying technical literacy levels. However, it can be noted from their qualitative responses that they tend to closely cluster at minimum levels, ranging from beginner level ("I can only manipulate basic operations in the 
computer" -Teacher C) to developing level ("I have average knowledge in using the software application" -Teacher A). There is a general indication to promote the digital literacy of the participants to an advanced level for blended learning transition.

Theme 2: A direct, intentional awareness of digital citizenship is sought. Relative to digital citizenship, some participants possess an awareness of the ethical considerations underlying digital citizenship only arising from general experience ("We have been trained about ethical standards of being a public servant" -Teacher G) while others indicate a need to heighten it ("I believe I have few knowledge when it comes to these ethical considerations" - Teacher B). These utterances generally suggest a need for more covert inputs on digital ethics so that awareness will be more direct and intentional.

Theme 3: Favorable dispositions about blended learning. Furthermore, a large majority of the participants held positive attitudes on the effectiveness ("I believe in the overall effectiveness of integrating the traditional classroom and online digital instruction" - Teacher C) and appropriateness ("With the kind of learners that we have right now, this strategy will work for sure" - Teacher E) of the blended learning. Hence, it can be said that the participants generally maintain a progressive outlook when it comes to blended learning.

Theme 4: Support to transition to an online modality of planning activities. Based mainly on their background, the participants conveyed confidence in the traditional modality of planning activities ("I have a lot of experiences in the traditional modality of planning activities" Teacher F). However, to plan blended activities, they generally seek more opportunities to be trained in the online modality ("I need to employ more practice in developing online skill instruction" - Teacher A). Thus, technical support with an emphasis on the online modality of planning activities is sought.

Theme 5: Planning a blended assessment grounded on existing practices and factors. Furthermore, it was disclosed by some participants that in planning blended assessment, they hold ground on the existing assessment practices ("I am used to following the unified assessment system set by the national in the traditional instruction" -Teacher B). They further stated that it depends on some factors ("If I will be given materials and references, I will not have any second thoughts to design a learner assessment system" - Teacher F). This result suggests a need to connect traditional assessment and online assessment with consideration of some factors. 
Theme 6: Emerging capabilities in personalizing instruction. The participants believed that the result of learner performance can be the basis of the pace of next instruction ("The result of the pupils' performance will put in the picture... whether you will jump higher or just take a little leap" -Teacher C) and selecting appropriate instruction ("It will be my basis to designing instructions suited to my learners' needs" -Teacher D). Most of the participants indicated an overall emerging capability to tailor instruction based on the results of the blended assessment.

Theme 7: Impartial readiness to facilitate blended student-student interaction. An impartial readiness to facilitate blended student-student interaction on the part of the participants can be observed, stemming from their limited experience ("I am not well equipped and a neophyte in the new educational system" -Teacher B) and their apprehension on learner response ("Not yet ready because I look after to my learners on how they respond to this new type of learning" -Teacher D). Thus, for most of the participants, facilitating student-student interaction in a blended learning situation appears to be a challenge to be addressed.

Theme 8: Affirmation on blended teacher-student interaction under favourable conditions. Moreover, there appears to be a positive response among the participants on their ability to facilitate teacher-student interaction mainly because of the similarities between the two modalities ("If we do video calls to our pupils, it seems that we do have a face-to-face session with them as well" -Teacher A). However, they held reservations that such interaction can be attained only under favourable conditions ("The implementation of online instruction can be effective only with parents' participation and commitment" -Teacher C). This result implies that blended teacher-student interaction is favoured but facilitative conditions must be met.

Theme 9: Ambivalence on facilitating blended student-content interaction. On the other hand, a generally uncertain view was expressed by the participants as regards their capability to facilitate blended student-content interaction. They pointed out restrictions ("No, because of some different factors such as my limited experiences, availability of resources and the participation of the parents themselves" -Teacher G) and need to improve ("Still trying to figure out how to have an engaging designed content yet" -Teacher E). These situations contribute to their ambivalence toward facilitating a blended student-content interaction.

Theme 10: Need to bridge traditional and online assessment. There are already baseline skills for traditional assessment implementation among the participants ("There are a lot of online assessment strategies available which I can modify" -Teacher D). But these baseline skills 
need to be maximized to online assessment implementation ("There is some assessment that is not applicable in online settings" -Teacher F). Hence, to bridge traditional and online assessment is needed to successfully implement a blended assessment.

Theme 11: Reflective practice of teaching in a blended learning setup. It was noted further that the all the participants demonstrate reflective teaching as a way for instructional improvement ("Yes, results will be the basis of the improvement of teaching methods, instructional materials, and assessment strategies" Teacher C) and gauge instructional effectiveness ("Yes since pupil performance would tell us, teachers, if the contents of teaching and learning we designed are working with them" -Teacher B). This reflective teaching practice can be maximized in blended learning transition.

Theme 12: Blended learning environment dependent on support. Mainly trained in establishing a traditional classroom environment, the participants articulated technical support for the online classroom environment ("Traditional classroom settings are very common, and I am very confident to establish that. But in online classroom settings, this is new to us especially for us -Teacher A). They further suggested that a blended learning environment is dependent on material support ("I am confident with regards to these modalities provided that the materials must be prepared appropriately for effective learning to happen" -Teacher D). This result calls for the importance of technical and material support to establish a blended learning environment.

Theme 13: Blended learning routines based on enabling factors. Lastly, there appears some degree of readiness among the participants when it comes to establishing blended learning routines. This readiness can be attributed to their efficacy ("I can establish blended learning routines by using my abilities and knowledge on how to handle both traditional and online classroom" -Teacher G) and exposure ("I think I know the basic skills in using ICT. I already taught my pupils in grade five the basic information of ICT as one of the components of our EPP subject" -Teacher C). These affirmations can be amplified to ensure a successful blended learning transition.

\subsection{Combined Results of Survey and Interview}

The two data sets generated from the survey and interviews were placed in a broader comparative perspective to determine points of convergence, elaboration, and divergence. The result of the analysis with the descriptive assessment is presented in Table 3. 
Table 3: Survey and Interviews on the Readiness on Blended Learning Transition

\begin{tabular}{|c|c|c|c|}
\hline Indicators & Quan & Qual & Assessment \\
\hline Technical literacy & $\begin{array}{l}\text { Slightly } \\
\text { ready }\end{array}$ & $\begin{array}{l}\text { Technical literacy ranging from } \\
\text { beginning to developing levels }\end{array}$ & $\begin{array}{l}\text { Quan and Qual } \\
\text { converge }\end{array}$ \\
\hline Digital citizenship & $\begin{array}{l}\text { Slightly not } \\
\text { ready }\end{array}$ & $\begin{array}{l}\text { Direct, intentional awareness of } \\
\text { digital citizenship is sought }\end{array}$ & $\begin{array}{l}\text { Quan and Qual } \\
\text { converge }\end{array}$ \\
\hline Dispositions & $\begin{array}{l}\text { Slightly } \\
\text { ready }\end{array}$ & $\begin{array}{l}\text { Favourable dispositions about } \\
\text { blended learning }\end{array}$ & $\begin{array}{l}\text { Quan and Qual } \\
\text { converge }\end{array}$ \\
\hline $\begin{array}{l}\text { Planning blended } \\
\text { activities }\end{array}$ & $\begin{array}{l}\text { Slightly } \\
\text { ready }\end{array}$ & $\begin{array}{l}\text { Support to transition to an online } \\
\text { modality of planning activities }\end{array}$ & $\begin{array}{l}\text { Quan is elaborated } \\
\text { by Qual }\end{array}$ \\
\hline $\begin{array}{l}\text { Planning blended } \\
\text { assessments }\end{array}$ & $\begin{array}{l}\text { Slightly } \\
\text { ready }\end{array}$ & $\begin{array}{l}\text { Planning a blended assessment } \\
\text { grounded on existing practices } \\
\text { and factors }\end{array}$ & $\begin{array}{l}\text { Quan is elaborated } \\
\text { by Qual }\end{array}$ \\
\hline $\begin{array}{l}\text { Personalizing } \\
\text { instruction }\end{array}$ & $\begin{array}{l}\text { Slightly not } \\
\text { ready }\end{array}$ & $\begin{array}{l}\text { Emerging capabilities in } \\
\text { personalizing instruction }\end{array}$ & $\begin{array}{l}\text { Quan and Qual } \\
\text { diverge }\end{array}$ \\
\hline $\begin{array}{l}\text { Facilitating } \\
\text { student-student } \\
\text { interaction }\end{array}$ & $\begin{array}{l}\text { Slightly not } \\
\text { ready }\end{array}$ & $\begin{array}{l}\text { Impartial readiness to facilitate } \\
\text { blended student-student } \\
\text { interaction }\end{array}$ & $\begin{array}{l}\text { Quan and Qual } \\
\text { converge }\end{array}$ \\
\hline $\begin{array}{l}\text { Facilitating } \\
\text { teacher-student } \\
\text { interaction }\end{array}$ & $\begin{array}{l}\text { Slightly } \\
\text { ready }\end{array}$ & $\begin{array}{l}\text { The affirmation on blended } \\
\text { teacher-student interaction under } \\
\text { favourable conditions }\end{array}$ & $\begin{array}{l}\text { Quan is elaborated } \\
\text { by Qual }\end{array}$ \\
\hline $\begin{array}{l}\text { Facilitating } \\
\text { student-content } \\
\text { interaction }\end{array}$ & $\begin{array}{l}\text { Slightly not } \\
\text { ready }\end{array}$ & $\begin{array}{l}\text { Ambivalence on facilitating } \\
\text { blended student-content } \\
\text { interaction }\end{array}$ & $\begin{array}{l}\text { Quan and Qual } \\
\text { converge }\end{array}$ \\
\hline $\begin{array}{l}\text { Implementing } \\
\text { blended } \\
\text { assessment }\end{array}$ & $\begin{array}{l}\text { Slightly not } \\
\text { ready }\end{array}$ & $\begin{array}{l}\text { Need to bridge traditional and } \\
\text { online assessment } \\
\text { implementation }\end{array}$ & $\begin{array}{l}\text { Quan is elaborated } \\
\text { by Qual }\end{array}$ \\
\hline $\begin{array}{l}\text { Evaluating and } \\
\text { reflecting }\end{array}$ & $\begin{array}{l}\text { Slightly not } \\
\text { ready }\end{array}$ & $\begin{array}{l}\text { The reflective practice of } \\
\text { teaching in a blended learning } \\
\text { setup }\end{array}$ & $\begin{array}{l}\text { Quan and Qual } \\
\text { diverge }\end{array}$ \\
\hline $\begin{array}{l}\text { Blended learning } \\
\text { environment }\end{array}$ & $\begin{array}{l}\text { Slightly } \\
\text { ready }\end{array}$ & $\begin{array}{l}\text { Blended learning environment } \\
\text { dependent on support }\end{array}$ & $\begin{array}{l}\text { Quan is elaborated } \\
\text { by Qual }\end{array}$ \\
\hline $\begin{array}{l}\text { Blended learning } \\
\text { routines }\end{array}$ & $\begin{array}{l}\text { Slightly } \\
\text { ready }\end{array}$ & $\begin{array}{l}\text { Blended learning routines based } \\
\text { on enabling factors }\end{array}$ & $\begin{array}{l}\text { Quan is elaborated } \\
\text { by Qual }\end{array}$ \\
\hline
\end{tabular}

Quan=quantitative result; Qual=qualitative result

The comparison of the quantitative survey result and qualitative interview result revealed three interesting points in the indicators of readiness on blended learning transition. 
First, accounting for each indicator of readiness, many quantitative descriptions, and qualitative themes converge. For example, in the indicator of technical literacy, the quantitative description shows that the teachers were slightly not ready which is complemented by the qualitative theme that teachers possess technical literacy ranging from beginner level to developing level only. The same can be said for the indicator of digital citizenship. While the quantitative description indicated a slightly not ready description, the qualitative theme suggested for the development of a direct, intentional awareness on digital citizenship.

Furthermore, in terms of dispositions, the teachers quantitatively described their readiness as slightly ready which was converged as they qualitatively expressed favourable dispositions about blended learning. The teachers also disclosed in the quantitative result that they are not slightly ready in facilitating student-student interaction in a blended setup which is supported by the qualitative result that they have impartial readiness to facilitate blended student-student interaction. Convergence can be similarly observed on the indicator of facilitating studentcontent interaction. The teachers quantitatively rated a slightly not ready level which is qualitatively matched as they revealed an ambivalent stance on the same indicator.

Second, there are also indicators of readiness in which the quantitative result is elaborated by the qualitative result. Hence, for instance, relative to planning blended activities, the teachers quantitatively obtained a slightly ready level. This is qualitatively explained that planning blended activities requires support systems, especially to online modality. This pattern can also be noted in the indicator of planning blended assessments. The quantitative results displayed a slightly ready level which is expounded in the qualitative results that planning blended assessments is grounded on existing assessment practices and factors. When it comes to the indicator of facilitating teacher-student interaction, the readiness was quantified as slightly ready. This is qualified as teachers elaborate their affirmation and pointing out particularly favourable conditions for such interaction to happen.

Moreover, the teachers in the quantitative result appeared to be slightly not ready in the indicator of implementing the blended assessment. They elaborated in the qualitative result a need to bridge traditional and online modalities which they already know and they desire to know respectively. On the other hand, the quantitative slight readiness of the teachers in establishing a blended learning environment is qualitatively expounded by the needed support to which a blended learning environment depends. Such an elaboration between quantitative and 
qualitative results is also evident in the indicator of blended learning routines. The teachers are slightly ready as indicated by the quantitative result to which they expounded some enabling factors in the qualitative result.

Third and not the least, an interesting point in comparing the indicators is the evident divergence between few quantitative and qualitative results. Rather than viewing this divergence as a discrepancy, the researchers consider this matter as a point to address a weakness by capitalizing on a strength. As an illustration, it can be noticed that, in the indicator of personalizing instruction, the teachers are slightly not ready as indicated by the quantitative result. This weakness can be answered by the qualitative result on the same indicator that reveals a theme of emerging capabilities of teachers to personalize instruction.

The same enlightenment can be applied in the divergence between the results for the indicator of evaluating and reflecting. While the teachers quantitatively rated a slightly not ready level to evaluate and reflect in a blended learning context, such a weakness can be responded by the qualitative propensity of the teachers for the reflective practice of teaching in a blended learning context.

\section{Discussion}

It should be stressed that educational technology integration is dependent on the readiness of individual teachers (Petko et al., 2018). The successful implementation of digital technology into the curriculum relies heavily on the readiness of the teachers (Singh \& Chan, 2014). Hence, this study found it important to ascertain the readiness of teachers on blended learning which is likely a promising direction in education in the post-COVID-19 period. As educational systems are searching for alternative approaches (Cahapay, 2020b) amid the age of social distancing measures (Cahapay, 2020c), schools seem to head towards blended learning modality.

The level of readiness of the teachers on technology integration has been widely reported in the related researches. The results are divergent (e.g. see Norizan et al., 2018; Tondeur et al., 2017 on a low level; Ng \& Cheng, 2019; Noh et al., 2013; Al-Awidi, 2017 on the moderate level; Singh \& Chan, 2014 on a high level). This global trend on the moderate level of teacher readiness on technology integration corroborates the quantitative results of the current study on the readiness of teachers on blended learning transition. 
Furthermore, it should be noted that while this inquiry mainly focused on the construct of readiness on blended learning transition, the qualitative results inevitably and constantly probed different facilitating and hindering factors. The vast body of researches highlights a complicated pattern of interconnected factors related to readiness and is expected to be predictors of the successful integration of technology in education (Player-Koro, 2012).

For example, Bingimlas (2009) found three factors that impede the readiness of the teachers on technology integration: "lack of confidence, competence, and accessibility to resources" (p.9). These factors are similar to the ones uncovered in this study. Koehler and Mishra (2009) further focused on experience as a factor. They elaborated that the inadequate experience of teachers on the application of educational technologies in education can be attributed to social and contextual factors that muddle the connection of technology and instruction. This condition does not encourage success for technology integration initiatives.

Other researchers such as Buabeng-Andoh (2012), Goktas et al. (2013), Singh and Chan (2014), and Maimun et al., (2017) enumerated more specific factors that facilitate or hinder teachers from integrating technology in instructional implementation. These factors cover teacher skills, school infrastructure, budget allocation, teacher confidence, quality technical support, workload, access to technology, teacher practices, structure of education systems, nature of curriculum, and peer support system.

Specifically, on the teacher experiences and practices as factors, an interesting point in the present research is the inevitable discussion about the holding of teachers on the traditional modalities. While blended learning combines traditional and online modalities, the teachers appeared to cling on the traditional modalities. This issue is also revealed by Bingimlas (2009). He found out that in the attempt to integrate technology in classroom instruction, teachers maintained high favour of traditional techniques.

All these factors mentioned were summed up by Sherry and Gibson (2002). They recommended that four factors should be taken into consideration when planning to introduce technology in schools. These are related to technological, individual, organizational, and institutional factors. These factors, directly and indirectly, appear in the qualitative results of the current study, thus should be seriously provided attention in the development of a comprehensive program to prepare teachers on blended learning modality. 


\section{Conclusion}

This work using a parallel mixed method design revealed points of convergence, elaboration, and divergence in the data sets. An interesting point can be further underscored in this conclusion that though quantitative and qualitative results diverge in some points, challenges on these facets of blended learning can be turned into opportunities for teachers in the conduct of blended learning in the new normal. A comprehensive view as regards the overall moderate readiness of teachers on blended learning transition is gained in this paper. This formative research provides practical assessment evidence that will serve as baseline data for the development of a responsive, appropriate, and relevant program to prepare the teachers for the blended learning modality of instructional implementation in a post-COVID-19 period.

This research is conducted in a challenging moment. There were modifications especially in the methods used. For example, personal interviews were not possible and a remote approach was employed. This method restricted possible interactions with the respondents to expound on certain issues. The relatively small sample was also focused on a single context and a certain level of education. The quantitative result is restrained by its ability to generalize while the qualitative result may have also suffered from reaching saturation.

Generally, it is recommended that the school head and teachers under this study should carefully consider the evidence gathered in this study in their instructional preparation toward an efficient and effective implementation. A teacher readiness program on blended learning should be designed by the school based on the empirical results of this study. Further assessment studies adopting a parallel mixed-method research design employed in the future is also highly suggested. Emphasis should be placed by researchers on addressing the weaknesses found in the data collection techniques and sample size in the current study.

\section{REFERENCES}

Al-Awidi, H., \& Aldhafeeri, F. (2017). Teachers' readiness to implement a digital curriculum in Kuwaiti schools. Journal of Information Technology Education: Research, 16, 105-126. https://doi.org/10.28945/3685

Balajadia, D. M. (2015). Gauging the ICT-based teaching readiness of pre-service teachers in the light of 21st-century education. PEOPLE: International Journal of Social Sciences, 1(1), 11-30. https://doi.org/10.20319/pijss.2015.s11.1130 
Barde, M. (2017). Teachers' readiness for integration of information communication and technology in the teaching of biology in secondary schools of Bauchi State, Nigeria (M.A. thesis). Retrieved from https://ir-library.ku.ac.ke/handle/

Bernardo, J. (2020, April 21). DepEd eyes blending online, classroom learning for next school year. $A B S-C B N N e w s$. Retrieved from https://news.abs-cbn.com/news/

Bingimlas, K. (2009). Barriers to the successful integration of ICT in teaching and learning environments: A review of the literature. Eurasia Journal of Mathematics, Science and Technology Education, 5(3), 235-245. https://doi.org/10.12973/ejmste/75275

Brooks, D. C., \& Grajek, S. (2020). Students' readiness to adopt fully remote learning. [Blog post]. Retrieved from https://er.educause.edu/blogs/

Buabeng-Andoh, C. (2012). An exploration of teachers' skills, perceptions and practices of ICT in teaching and learning in the Ghanaian second cycle schools. Contemporary Educational Technology, 3(1), 36-49. https://doi.org/10.30935/cedtech/6066

Cahapay, M. B. (2020a). Reshaping assessment practices in a Philippine teacher education institution during the Coronavirus Disease 2019 crisis. Pedagogical Research, 5(4), em0079. https://doi.org/10.29333/pr/8535

Cahapay, M. B. (2020b). Rethinking education in the new normal Post-COVID-19 era: A curriculum studies perspective. Aquademia, 4(2), ep20018. https://doi.org/10.29333/aquademia/8315

Cahapay, M. B. (2020c). Social distancing practices of residents in a Philippine region with low risk of COVID-19 infection. European Journal of Environment and Public Health, 4(2), em0057. https://doi.org/10.29333/ejeph/8455

Christensen, R. \& Knezek, G. (2017). Readiness for integrating mobile learning in the classroom: Challenges, preferences and possibilities. Computers in Human Behavior, 76, 112-121. https://doi.org/10.1016/j.chb.2017.07.014

Creswell. J. W. (2003) Research design: Qualitative, quantitative and mixed methods approaches. London: Sage. 2nd ed.

Cuhadar, C. (2018). Investigation of pre-service teachers' levels of readiness to technology integration in education. Contemporary Educational Technology, 9(1), 61-75. https://doi.org/10.30935/cedtech/6211 
DiBella, K. S., Williams, K. G., \& Glover, L.C. (2015). Improving pre-service teachers' readiness to integrate technology with cross-curricular adaptations. Journal of Education and Human Development, 4(2), 84-97. https://doi.org/10.15640/jehd.v4n2_1a9

Goktas, Y., Yildirim, S., \& Yildirim, Z. (2009). Main barriers and possible enablers of ICTs integration into pre-service teacher education programs. Educational Technology \& Society, 12(1), 193- 204. Retrieved from https://eric.ed.gov/?id=EJ833426

Graham, C. R. (2013). Emerging practice and research in blended learning. In M. G. Moore (Ed.), Handbook of distance education, (3rd ed., pp. 333-350). New York: Routledge.

Graham, C. R., Borup, J., Pulham, E., \& Larsen, R. (2019). K-12 blended teaching readiness: Model and instrument development. Journal of Research on Technology in Education, 51(3), 239-258. https://doi.org/10.1080/15391523.2019.1586601

Huang, R. M., Lanqin, Z., \& Haisen, Z. (20009). The theory of curriculum design based on blended learning. E-education Research, 9-14. https://doi.org/10.1007/978-3-54085170-7_6

Ifinedo, E., Saarela, M., \& Hämälänen, T. (2019). Analysing the Nigerian teacher's readiness for technology integration. International Journal of Education and Development using Information and Communication Technology, 15(3), 34-52. Retrieved from https://files.eric.ed.gov/fulltext/EJ1227419.pdf

Koehler, M. J. \& Mishra, P. (2009). What is technological pedagogical content knowledge? Contemporary Issues in Technology and Teacher Education, 9(1), 60-70. Retrieved from https://eric.ed.gov/?id=EJ904583

Maimun, L. A., Wan, \& Isa, M. (2017). The level of knowledge and the readiness of Islamic education teachers on the use of multimedia. ASEAN Comparative Education Research Journal on Islam and Civilization, 1(11), 1-13. Retrieved from https://www.researchgate.net/publication/

Markle, R. S. (2016). Exploring teacher readiness: What features of professional development enhance motivation to implement technology innovations? (Doctoral dissertation). Retrieved from https://scholarcommons.sc.edu/etd/

Morse, J. M. (1991). Approaches to qualitative-quantitative methodological triangulation. Nursing Research, 40(2), 120-123. https://doi.org/10.1097/00006199-199103000-00014 
Mousa, R. M., \& Kalonde, G. (2019). Saudi Arabia's female middle school mathematics teachers' readiness and attitudes towards STEM digital technology integration in classrooms. In P.H. Bull \& J. Keengwe (Eds.), Handbook of Research on Innovative Digital Practices to Engage Learners (pp. 177-197). Hershey, PA: IGI Global. https://doi.org/10.4018/978-1-5225-9438-3.ch009

Ng, W. S., \& Cheng, G. (2019). Integrating drone technology in STEM education: A case study to assess teachers' readiness and training needs. Issues in Informing Science and Information Technology, 16, 61-70. https://doi.org/10.28945/4288

Noh, N. M., Mustafa, H.M., \& Ahmad, C.N.C. (2013). Predictive relationship between technology acceptance readiness and the intention to use Malaysian EduwebTV among library and media teachers. Procedia - Social and Behavioral Sciences 116, 144-148. https://doi.org/10.1016/j.sbspro.2014.01.182

Norberg, A., Dziuban, C. D., \& Moskal, P. D. (2011). A time-based blended learning model. On the Horizon, 19(3), 207-216. https://doi.org/10.1108/10748121111163913

Norizan, A. R., Hussien, A., \& Yasmin, S. (2018). English language teachers' readiness for the application of technology towards Fourth Industrial Revolution demands. Asia-Pacific Journal of Information Technology and Multimedia, 7(2), 89-98. https://doi.org/10.17576/apjitm-2018-0702(02)-08

Obana, J. (2020, March 18). Could educational technology be a 'holy grail' amid Covid-19 crisis? The Manila Times. Retrieved from https://www.manilatimes.net/2020/03/18/business/

Patrinos, H. A., \& Shmis, T. (2020). Can technology help mitigate the impact of COVID-19 on education systems in Europe and Central Asia? [Blog post]. Retrieved from https://blogs.worldbank.org/europeandcentralasia/

Petko, D., Frasse, D., \& Cantieni, A. (2018). The interplay of school readiness and teacher readiness for educational technology integration: A structural equation model. Interdisciplinary Journal of Practice, Theory, and Applied Research, 35(1), 1-18. https://doi.org/10.1080/07380569.2018.1428007

Player-Koro, C. (2012). Factors influencing teachers use of ICT in education. Education Inquiry, 3(1), 93-108. https://doi.org/10.3402/edui.v3i1.22015 
Ross, B., \& Gage, K. (2006). Global perspectives on blended learning: Insight from WebCT and our customers in higher education. In C. J. Bonk, \& C. R. Graham (Eds.), Handbook of blended learning: Global perspectives, local designs, (pp. 155-168). San Francisco: Pfeiffer, Zamir \& Thomas

Sherry, L., \& Gibson, D. (2002). The path to teacher leadership in educational technology. Contemporary Issues in Technology and Teacher Education, 2(2), 178-203. Retrieved from https://www.learntechlib.org/primary/p/10751/

Singh, T. K. R., \& Chan, S. (2014). Teacher readiness on ICT integration in teaching-learning: A Malaysian case study. International Journal of Asian Social Science, 4(7), 874-885. Retrieved from http://www.aessweb.com/pdf-files/

Suen, L. W., Huang H., \& Lee, H. (2014). A comparison of convenience sampling and purposive sampling. Hu Li Za Zhi, 61(3), 105-111. https://dx.doi.org/10.6224/JN.61.3.105

Tamban, V. E., \& Maningas, O. B., (2020). Research capability of public school teachers: A basis for research capability enhancement program. PEOPLE: International Journal of Social Sciences, 6(1), 222-235. https://doi.org/10.20319/pijss.2020.61.222235

Teddie, C. \& Tashakkori, A. (2009). Foundations of mixed methods research: Integrating quantitative and qualitative approaches in the social and behavioural sciences. Thousand Oaks, CA: SAGE Publications, Inc.

Tondeur, J., Aesaert, K., van Braak, J., Pynoo, B., Freyman, N., \& Erstadt, O. (2017). Developing a validated instrument to measure pre-service teachers' ICT competencies: meeting the demands of the 21st-century. British Journal of Educational Technology, 48(2), 462-472. https://doi.org/10.1111/bjet.12380

Zamir, S. \& Thomas, M. (2019). The effects of university teachers' perception, attitude and motivation on their readiness for the integration of ICT in classroom teaching. Journal of Education and Educational Development, 6(2), 308-326. https://doi.org/10.22555/joeed.v6i2.2712 